\title{
The Association of the Prolonged Use of Personal Protective Equipment and Face Mask During COVID-19 Pandemic With Various Dermatologic Disease Manifestations: A Systematic Review
}

\author{
Ghassan M. Barnawi ${ }^{1}$, Azhar M. Barnawi ${ }^{2}$, Sahal Samarkandy ${ }^{1}$ \\ 1. Dermatology, College of Medicine at King Saud bin Abdulaziz University for Health Sciences, King Abdulaziz Medical \\ City, Jeddah, SAU 2. Family Medicine, Armed Forces Hospital, Prince Mansour Military Hospital for Community \\ Medicine, Taif, SAU
}

Corresponding author: Ghassan M. Barnawi, gn-al@hotmail.com

\begin{abstract}
COVID-19 is a novel coronavirus that represents a great global health concern. It is transmitted between individuals through respiratory particles, and as there is no established effective treatment currently for the virus, it is necessary to use protective strategies such as face masks. Healthcare providers and individuals serving outdoors are required to work for long durations wearing personal protective equipment (PPE). Wearing such protective equipment may have short- or long-term effects on the skin health of these individuals. We aim to assess the prevalence and types of dermatological manifestations associated with wearing PPE for a long time during the COVID-19 pandemic period by reviewing the previous studies conducted on this subject.
\end{abstract}

The medical literature, including the databases of PubMed and Google Scholar, from 2019 to 2021 was explored. The search terms included a combination of "Impact of PPE and dermatological outcome," "Wearing PPE for a long time and dermatological manifestations," "Face mask-wearing and dermatological complications," and "Wearing PPE and dermatological manifestations." The inclusion criteria are original full-text articles that reported the association of wearing PPE and dermatological manifestations and outcomes.

A total of 70 articles were obtained, among which only 10 articles were eligible for the inclusion criteria. These 10 studies included a total number of 7,643 participants and covered different countries of the world. The extracted data were summarized in a table to facilitate the collection of the important findings.

Dermatological complications are frequently reported in people wearing PPE and face masks, especially the ones caused due to PPE among healthcare providers as they tend to use these protective measures for longer durations.

Review began 06/15/2021 Review ended 07/09/2021 Published 07/21/2021

\section{(c) Copyright 2021}

Barnawi et al. This is an open access article distributed under the terms of the Creative Commons Attribution License CC-BY 4.0., which permits unrestricted use, distribution, and reproduction in any medium, provided the original author and source are credited.
Categories: Dermatology

Keywords: dermal manifestations, covid-19, ppe, long duration, impact

\section{Introduction And Background}

The novel strain of coronavirus was first reported in Wuhan, China, in late November 2019 [1]. Now known as COVID-19, it has progressed to become a global public health emergency [2]. Symptoms typically include fever, a sore throat, shortness of breath, headaches, and coughing; however, asymptomatic patients are also known to exist [2]. Until May 2020, there was no approved vaccine for COVID-19 [3], and although they do now exist, active treatment is still evolving, revolving mostly around supportive care such as supplementation of oxygen and maintaining continuous positive airway pressure [4]. Transmission between humans occurs at high rates, spreading via droplet particulates or physical contact with a contaminated surface, causing all mundane social interactions from breathing to conversing a pathway for infection. [3]. For this reason, it was deemed necessary to enforce preventive strategies at the respiratory level, the most widespread being the use of face masks as a form of personal protective equipment (PPE) when within $2 \mathrm{~m}$ of another person or in enclosed spaces [5]. In high contagion areas, the forms of PPE required are more extreme, with some offering protection to the nose, mouth, ears, eyes, hands, and any other exposed areas such as the head [6]. In the majority of cases, PPE is restricted to respiratory protective equipment, most commonly a surgical or cotton mask, although some visors are available [6]. These have been shown to offer the highest preventive capabilities by serving as an immediate barrier between the respiratory tract and the surrounding environment [7]. The efficacy of face masks is highly reliant on how well it fits the contours of each individual face, the material, and the health of the individual in question [7]. This has led to increased popularity in respirator masks, which are being designed to create an adaptable facial seal, while also being recyclable - a definite improvement in traditional surgical masks [7]. 
During the COVID-19 pandemic, both healthcare workers (HCWs) and the general population have had a legal obligation to wear PPE in public at all times, be it at work or in transit. This has led to some unforeseen consequences such as an apparent increased susceptibility to adverse skin reactions [8]. This is so far attributed to factors related to moisture, excessive sweating, and friction caused by near-constant exposure to the fabrics, synthetic or otherwise, of any PPE. In addition, evidence suggests that the higher performance filtration PPEs are associated with increased dermatological conditions when compared to the traditional medical mask [9].

The epidemiology of skin diseases related to masks is yet to be widely studied, with the majority of such work being consigned to simple case reports or small local studies [10]. However, as the medical profession demands a near-constant use of respiratory PPE at the very least and for considerable periods of time, it has become necessary to understand and assess the various dermatological manifestations and adverse skin reactions that are being increasingly reported with the prolonged use of PPE. With this aim in mind, we found it necessary to begin with a review of all available material on the subject for a more well-founded and encompassing view of the problem.

\section{Review}

\section{Methods}

The PRISMA (Preferred Reporting Items for Systematic Reviews and Meta-Analysis) checklist [11] was used as a guideline to compile this systematic review.

An in-depth search of electronic databases such as PubMed and Google Scholar was conducted. Several keywords were used to locate relevant articles.

These were:

• "Impact of PPE and dermatological outcome"

- "Wearing PPE for a long time and dermatological manifestations"

• "Face mask-wearing and dermatological complications"

• "Wearing PPE and dermatological manifestations."

Inclusion criteria were as follows:

- Article must be dated between 2019 and 2021.

- Only complete articles were considered.

- Articles should be centered around using PPE for long periods, preferably with HCWs as the study sample (not mandatory).

A final review of the eligible documents was then carried out, with incomplete or overlapping studies being excluded further (Figure 1). 


\section{Cureus}

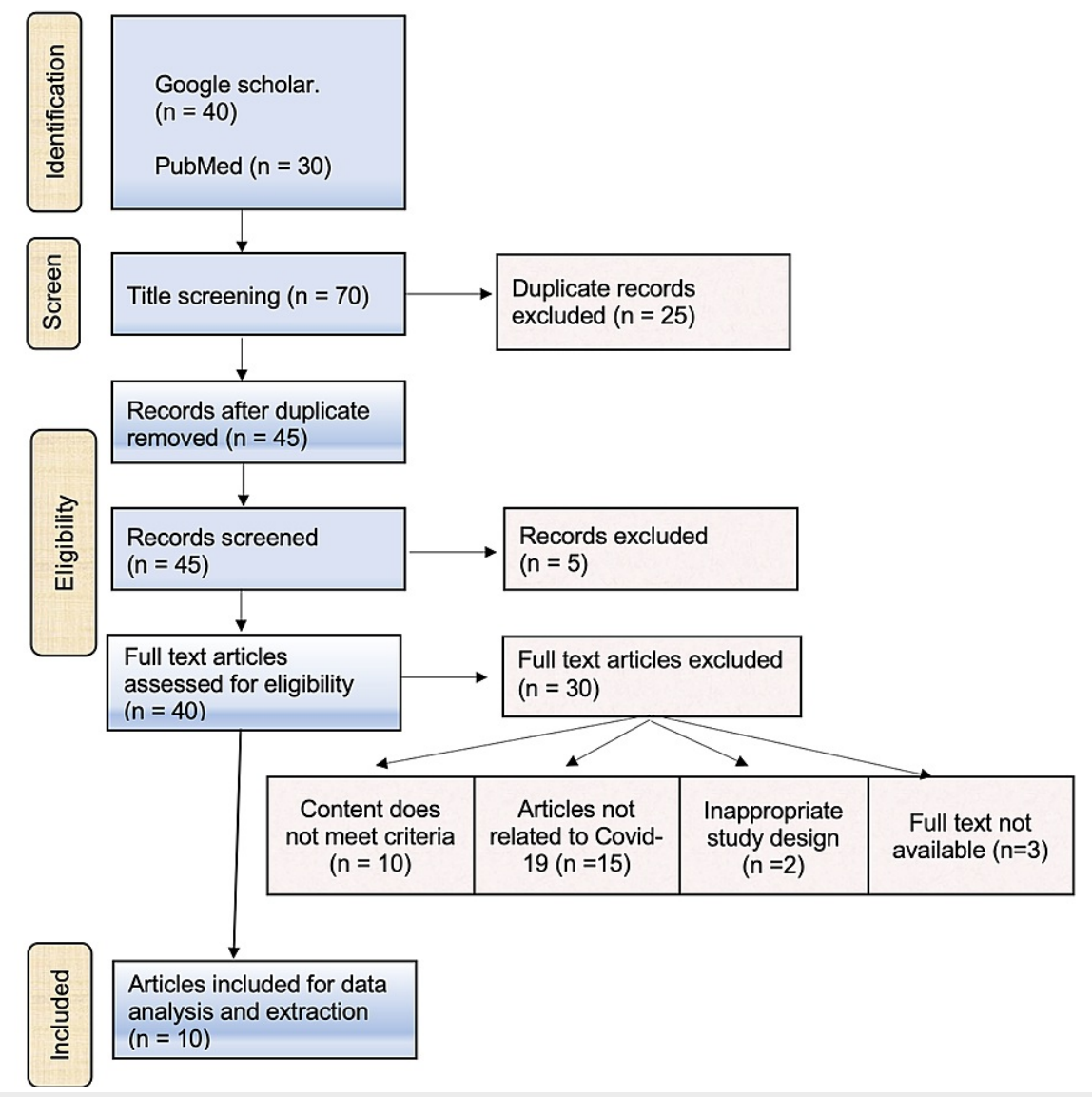

\section{FIGURE 1: Planning of eligible criteria}

\section{Data review and analysis}

Stage one in the data review included a preliminary extraction of data via excel. This was proceeded by a more in-depth review in which research articles published by one research group examining similar variables were summarized in an attempt to prevent errors of duplication.

\section{Results}

Of the initial 70 articles, only 10 met the full inclusion criteria [12-21] (Table 1). The ten included studies varied slightly in their study designs; for example, seven of them were cross-sectional studies $[12,13,15,18$ 21], one was a prospective study [14], and one was quantitative descriptive [17]. Only one study did not specify the used study design [16].

\begin{tabular}{|c|c|c|c|c|c|}
\hline $\begin{array}{l}\text { Author and } \\
\text { Publication } \\
\text { Year }\end{array}$ & $\begin{array}{l}\text { Study } \\
\text { Design }\end{array}$ & $\begin{array}{l}\text { Population } \\
\text { and Sample } \\
\text { Size }\end{array}$ & Settings & $\begin{array}{l}\text { Protective } \\
\text { Tools } \\
\text { Investigated } \\
\text { and } \\
\text { Duration }\end{array}$ & Results and Main Findings \\
\hline $\begin{array}{l}\text { Uthayakumar et } \\
\text { al. } 2021 \text { [12] }\end{array}$ & Rapid report & $\begin{array}{l}\text { - } 67 \text { staff } \\
\text { members } \\
\text { (nurses, } \\
\text { doctors, } \\
\text { pharmacists, } \\
\text { radiographers, } \\
\text { administrative, } \\
\text { physiotherapy, } \\
\text { laboratory }\end{array}$ & London, UK & - & $\begin{array}{l}\text { *Moderate eczema } 91 \% \text {, mild eczema } 9 \% \text {, } \\
\text { moderate acne } 33 \% \text {, and mild acne } 67 \% .{ }^{*} \text { The } \\
\text { most prevalent dermatoses were irritant contact } \\
\text { hand dermatitis ( } 45 \%) \text {, acne/folliculitis }(24 \%) \text {, and } \\
\text { eczema flare-up ( } 28 \%) .{ }^{*} \text { One patient was } \\
\text { diagnosed with Darier's disease, exacerbated by } \\
\text { PPE. *Hand eczema is one of the most common } \\
\text { occupational diseases, and given the ongoing } \\
\text { use of PPE and increased hand hygiene in both } \\
\text { hospitals and public settings, we are likely to see } \\
\text { an increase in these conditions, in both primary } \\
\text { and secondary care. }{ }^{*} \text { With the use of PPE, there }\end{array}$ \\
\hline
\end{tabular}




\section{Cureus}

\begin{tabular}{|c|c|c|c|c|c|}
\hline & & $\begin{array}{l}\text { technicians, } \\
\text { domestic) - } \\
\text { With age } \\
\text { range of } 23-60 \\
\text { years }\end{array}$ & & & $\begin{array}{l}\text { was a marked increase in the impact of skin } \\
\text { conditions; } 70 \% \text { reported a significant adverse } \\
\text { effect on their work or study, and } 86 \% \text { on well- } \\
\text { being. *Dryness and associated irritation, in } \\
\text { addition to pain and pruritus, were the commonly } \\
\text { described symptoms and contributed to feelings } \\
\text { of anxiety. *During COVID- } 19 \text {, the high prevalence } \\
\text { of skin damage is in healthcare workers, which is } \\
\text { corroborated in the findings from this study. }\end{array}$ \\
\hline $\begin{array}{l}\text { Purushothaman } \\
\text { et al. } 2021 \text { [13] }\end{array}$ & $\begin{array}{l}\text { Cross- } \\
\text { sectional }\end{array}$ & $\begin{array}{l}-250 \\
\text { healthcare } \\
\text { workers - With } \\
\text { an age of } 20- \\
48 \text { years }\end{array}$ & $\begin{array}{l}\text { SRM Medical } \\
\text { College } \\
\text { Hospital, } \\
\text { Kattankulathur, } \\
\text { India }\end{array}$ & $\begin{array}{l}\text { - The use of } \\
\text { N95 } \\
\text { respirator } \\
\text { and surgical } \\
\text { face masks } \\
\text { - Wearing } \\
\text { duration of } \\
\text { at least } 4 \\
\text { hours/day }\end{array}$ & $\begin{array}{l}{ }^{*} \text { Excessive sweating around the mouth } 67.6 \% \text {, } \\
\text { difficulty in breathing on exertion } 58.2 \% \text {, acne } \\
56 \% \text {, itchy nose } 52 \% \text {, skin rashes/redness } 39 \% \text {. } \\
{ }^{*} \text { The prolonged use of face masks induces } \\
\text { difficulty in breathing on exertion and excessive } \\
\text { sweating around the mouth to the HCWs, which } \\
\text { results in poorer adherence and increased risk of } \\
\text { susceptibility to infection. }\end{array}$ \\
\hline $\begin{array}{l}\text { Abiakam et al. } \\
2021[14]\end{array}$ & $\begin{array}{l}{ }^{*} \text { Prospective } \\
\text { using a } \\
\text { survey } \\
\text { divided into } \\
\text { distinct } \\
\text { phases }\end{array}$ & $\begin{array}{l}\text { - } 108 \text { staff of } \\
\text { intensive care } \\
\text { from a single } \\
\text { center for the } \\
\text { prevalence of } \\
\text { adverse skin } \\
\text { reactions } \\
\text { during } 24 \text { of } \\
\text { using PPE at } \\
\text { different } \\
\text { duration } \\
\text { periods - } 307 \\
\text { HCWs from } \\
\text { different } \\
\text { professional } \\
\text { backgrounds }\end{array}$ & $\begin{array}{l}\text { UK NHS } \\
\text { centers }\end{array}$ & $\begin{array}{l}\text { - Full } \\
\text { protection } \\
\text { PPE, eye } \\
\text { protection, } \\
\text { gloves, } \\
\text { gown - The } \\
\text { mean time } \\
\text { of using } \\
\text { PPE was } 9.2 \\
\text { hours }\end{array}$ & $\begin{array}{l}{ }^{*} \text { Adverse skin reactions with the bridge of the } \\
\text { nose } 96 \% \text { and ears } 30 \% .{ }^{*} \text { The most common skin } \\
\text { reactions included redness blanching } 33 \% \text {, } \\
\text { itchiness } 22 \% \text {, and pressure damage } 12 \% \text {. }{ }^{*} \text { The } \\
\text { use of PPE leads to an array of skin reactions at } \\
\text { various facial locations of HCWs. }{ }^{*} \text { Modifications } \\
\text { to PPE designs are required to accommodate a } \\
\text { range of face shapes and appropriate materials to } \\
\text { improve device safety. *Improvements in } \\
\text { guidelines are required for PPE usage to protect } \\
\text { skin health. }\end{array}$ \\
\hline $\begin{array}{l}\text { Techasatian et } \\
\text { al. } 2020 \text { [15] }\end{array}$ & $\begin{array}{l}\text { Prospective } \\
\text { cross- } \\
\text { sectional }\end{array}$ & $\begin{array}{l}-833 \\
\text { participants of } \\
\text { the general } \\
\text { population } \\
\text { (there were } \\
\text { HCWs among } \\
\text { participants) - } \\
\text { Age of } 18 \\
\text { years and } \\
\text { older }\end{array}$ & $\begin{array}{l}\text { Khon Kaen } \\
\text { University, } \\
\text { Faculty of } \\
\text { Medicine, } \\
\text { Thailand }\end{array}$ & $\begin{array}{l}\text { - Four types } \\
\text { of face } \\
\text { masks: } \\
\text { surgical } \\
\text { (63.15\%), } \\
\text { cloth masks } \\
(30.05 \%) \text {, } \\
\text { surgical } \\
\text { masks } \\
\text { covered by } \\
\text { a piece of } \\
\text { cloth }(1 \%), \\
\text { N95 masks } \\
\text { (0.72\%) }\end{array}$ & $\begin{array}{l}{ }^{*} \text { The prevalence of adverse skin reactions on the } \\
\text { skin underneath the face masks was } 54.5 \% .{ }^{*} \text { The } \\
\text { most frequent ASRs were acne ( }(39.9 \%) \text {, rashes } \\
\text { on face ( } 18.4 \%) \text {, and itchy symptoms }(15.6 \%) \text {. } \\
{ }^{*} \mathrm{HCW} \text { had adverse skin reactions related to face } \\
\text { masks higher than non-HCW participants. } \\
\text { *Wearing a surgical mask showed a higher risk of } \\
\text { adverse skin reactions compared to wearing a } \\
\text { cloth mask. *Wearing a face mask } 4 \text { to } 8 \\
\text { hours/day and more than } 8 \text { hours/day increased } \\
\text { the risk of adverse skin reactions on the face } \\
\text { compared to wearing a face mask fewer or longer } \\
\text { than } 4 \text { hours/day. }{ }^{*} \text { Not changing the mask after } \\
\text { use every day was a risk factor showing } 1.5 \text { times } \\
\text { the risk of having an adverse skin reaction. }\end{array}$ \\
\hline \multirow[t]{2}{*}{$\begin{array}{l}\text { Yuan et al. } 2020 \\
\text { [16] }\end{array}$} & - & - $129 \mathrm{HCPs}$ & $\begin{array}{l}\text { Hospital of } \\
\text { Zhejiang } \\
\text { University } \\
\text { School of } \\
\text { Medicine, } \\
\text { China }\end{array}$ & - L3PPE & $\begin{array}{l}{ }^{*} 94.57 \% \text { healthcare professionals experienced } \\
\text { discomfort while wearing L3PPE to treat patients } \\
\text { with COVID-19. *Adverse skin reactions including } \\
\text { facial skin indentation, rash, and dermatitis. } \\
{ }^{*} \text { Facial skin indentation was more prevalent } \\
\text { among seniors }(70.9 \%) \text {, rash was more prevalent } \\
\text { among nurses }(25.9 \%) \text {, and dermatitis was more } \\
\text { prevalent among juniors ( } 46.7 \%) \text {. }{ }^{*} \text { More attention } \\
\text { should be offered to healthcare personnel } \\
\text { wearing L3PPE to treat patients with COVID-19 } \\
\text { because they are susceptible to developing } \\
\text { adverse reactions. }\end{array}$ \\
\hline & & & & & $\begin{array}{l}{ }^{*} \text { The incidence of ADRs to the N95 mask was } \\
95.1 \% \text {, that to latex gloves was } 88.5 \% \text {, and that }\end{array}$ \\
\hline
\end{tabular}




\section{Cureus}

\begin{tabular}{|c|c|c|c|c|c|}
\hline $\begin{array}{l}\text { Hu et al. } 2020 \\
{[17]}\end{array}$ & $\begin{array}{l}\text { Quantitative } \\
\text { descriptive }\end{array}$ & - 61 HCWs & Hubei, China & $\begin{array}{l}\text { - N95 } \\
\text { masks, latex } \\
\text { gloves, } \\
\text { protective } \\
\text { clothing }\end{array}$ & $\begin{array}{l}\text { to protective clothing was } 60.7 \% .{ }^{*} \text { The most } \\
\text { common ASRs among HCWs wearing N95 masks } \\
\text { were nasal bridge scarring ( } 68.9 \% \text { ) and facial } \\
\text { itching ( } 27.9 \% \text { ) after using N95 for } 12 \text { hours/day } \\
\text { for } 3.5 \text { months. }{ }^{*} \text { The most common ADRs among } \\
\text { HCWs wearing latex gloves were dry skin } \\
(55.7 \%) \text {, itching ( } 31.2 \%) \text {, and rash ( } 23.0 \%) \text { with } \\
\text { average usage of } 10 \text { hours for } 3.5 \text { months. }{ }^{*} \text { The } \\
\text { most common ADRs among HCWs wearing } \\
\text { protective clothing were dry skin ( } 36.1 \%) \text { and } \\
\text { itching ( } 34.4 \%) .{ }^{*} \text { The long-term use of PPE in } \\
\text { Hubei Province found that most HCWs have } \\
\text { adverse skin reactions when wearing masks, } \\
\text { gloves, and protective clothing. }\end{array}$ \\
\hline $\begin{array}{l}\text { Jian et al. } 2020 \\
\text { [18] }\end{array}$ & $\begin{array}{l}\text { Multicenter, } \\
\text { cross- } \\
\text { sectional }\end{array}$ & $\begin{array}{l}\text { - } 4306 \text { medical } \\
\text { staff }\end{array}$ & $\begin{array}{l}161 \text { hospitals } \\
\text { in China }\end{array}$ & $\begin{array}{l}\text { PPE levels } 2 \\
\& 3\end{array}$ & $\begin{array}{l}{ }^{*} \text { The overall prevalence of skin injuries was } \\
42.8 \% \text {; pressure injuries, moist-associated skin } \\
\text { damage, and skin tear. *'Sweating, daily wearing } \\
\text { time more than } 4 \text { hours, male, and grade } 3 \text { PPE } \\
\text { were associated with skin injuries. }{ }^{*} \text { The skin } \\
\text { injuries among medical staff are serious, with } \\
\text { insufficient prevention and treatment. }\end{array}$ \\
\hline $\begin{array}{l}\text { Coelho et al. } \\
2020 \text { [19] }\end{array}$ & $\begin{array}{l}\text { Cross- } \\
\text { sectional }\end{array}$ & $\begin{array}{l}-1106 \text { health } \\
\text { professionals }\end{array}$ & $\begin{array}{l}\text { - Ceara in } \\
\text { Brazil }\end{array}$ & - & $\begin{array}{l}{ }^{*} \text { The prevalence of pressure injuries related to the } \\
\text { use of PPE was } 69.4 \% \text {, with an average of } 2.4 \\
\text { injuries/professional. }{ }^{*} T \text { The significant factors were } \\
\text { age under } 35 \text { years, working and wearing PPE for } \\
\text { more than } 6 \text { hours a day, in hospital units, and } \\
\text { without the use of inputs for protection. }\end{array}$ \\
\hline $\begin{array}{l}\text { Shanshal et al. } \\
2020 \text { [20] }\end{array}$ & $\begin{array}{l}\text { Cross- } \\
\text { sectional } \\
\text { observational }\end{array}$ & $\begin{array}{l}-276 \\
\text { healthcare } \\
\text { providers }\end{array}$ & $\begin{array}{l}\text { - The major } \\
\text { hospitals in } \\
\text { Iraq }\end{array}$ & - & $\begin{array}{l}{ }^{\star} \text { The prevalence of hygiene-related hand } \\
\text { dermatitis was } 83 \% \text {. }{ }^{*} \text { The prevalence of PPE- } \\
\text { related dermatoses was } 73.5 \% \text {. }{ }^{*} \text { The types of } \\
\text { PPE-related dermatoses included pressure } \\
\text { injuries } 51.9 \% \text {, acne } 33.1 \% \text {, non-gloves CD } \\
29.9 \% \text {, non-specific rash } 17.5 \% \text {, urticaria } 9.1 \% \text {, } \\
\text { and skin infections } 3.2 \% \text {. }\end{array}$ \\
\hline $\begin{array}{l}\text { Christopher et } \\
\text { al. } 2020 \text { [21] }\end{array}$ & $\begin{array}{l}\text { Cross- } \\
\text { sectional }\end{array}$ & - $200 \mathrm{HCWs}$ & $\begin{array}{l}\text { - Siloam } \\
\text { Hospitals, } \\
\text { Indonesia }\end{array}$ & $\begin{array}{l}\text { - PPE levels } \\
2 \& 3\end{array}$ & $\begin{array}{l}{ }^{*} \text { The prevalence of skin reactions was } 66.5 \% \text {; } \\
73.7 \% \text { females, } 82.7 \% \text { doctors, wearing levels } 2 \\
\text { and } 3 \text { PPE } 43.6 \% \text { and } 37.6 \% \text {, respectively. }{ }^{*} \text { Most } \\
\text { affected regions were cheeks and chin }(69.9 \%) \text {. } \\
{ }^{*} \text { The most common symptoms were } \\
\text { dryness/tightness }(63.9 \%) \text { and acne }(77.4 \%) \text {. } \\
\text { 'Sex, age group classification, level of PPE worn, } \\
\text { hand hygiene frequency, and duration of PPE } \\
\text { worn daily ( } \geq 7 \text { hours) were factors considerably } \\
\text { associated with adverse skin reactions to PPE. } \\
{ }^{*} \text { Adverse skin reactions to PPE are common } \\
\text { among HCWs in Indonesia. }\end{array}$ \\
\hline
\end{tabular}

\section{TABLE 1: Literature review of the 10 articles that met the full inclusion criteria}

PPE, Personal protective equipment; HCWs, healthcare workers; ASR, adverse skin reaction; HCP, healthcare professional; ADR, adverse drug reaction.

The total number of participants in all 10 studies amounted to 7,643 participants; of these 833 (10.89\%) were of the general population and the remaining 6,810 (89.1\%\%) were HCWs, both in private and public care sectors [15].

Concerning study locations, two were performed in the United Kingdom [12,14]; three studies in China [1618]; and single studies from India [13], Thailand [15], Brazil [19], Iraq [20], and Indonesia [21]. There were three studies that did not specify the PPE investigated and used by the participants [12,19,20].

The included studies varied in the results and findings, so the finding of each study is explored individually. 
The rapid report, which included only 67 staff members, reported that eczema was the most common skin condition (91\%), followed by irritant hand dermatitis (45\%) and acne (33\%). Hand eczema was the most common occupational disease due to the prolonged usage of PPE and increased hand hygiene. These skin reactions were found to affect the work of $70 \%$ of participants and affect the well-being of $86 \%$ [12].

A study on 250 HCWs investigated the wearing of N95 respirator and surgical masks for a period exceeding four hours daily and reported that acne was prevalent among $56 \%$ of participants, followed by nasal itching (52\%), and skin rashes (39\%). The prolonged usage of face masks affected the HCWs negatively, leading to poor adherence to legal obligations of constant usage of PPE and thus an increased risk of susceptibility to infection [13].

One study reported in the first phase that the prevalence of adverse skin reactions occurred around the nose (96\%) and ears (30\%); these were most commonly restricted to redness blanching as the main complication (33\%), followed by itchiness (22\%), and lastly pressure damage (12\%). Moreover, the study reported that an average of 9.2 hours of constant exposure to PPE was necessary to exhibit these dermatological symptoms [14].

The study that was conducted on the general population reported a prevalence of $54.5 \%$ of adverse skin reactions on the skin underneath the face masks. The most common adverse reaction was acne (39.9\%), followed by rashes (18.4\%), and itchiness (15.6\%). The study reported several risk factors for adverse skin reactions, including wearing a face mask for four to eight hours daily and not changing the mask after daily usage [15].

One study investigated the dermal impact of wearing level-3 PPE (L3PPE). It reported that 94.57\% of healthcare professionals experienced discomfort related to wearing L3PPE. The most common adverse skin reactions were facial skin indentations, rashes, and dermatitis. In addition, skin indentation was more prevalent among seniors, whereas rashes and dermatitis were more prevalent among nurses and junior medical staff [16].

Another study that investigated the effect of N95 masks, latex gloves, and protective clothing by HCWs reported the incidence of adverse skin reactions based on the type of PPE in question. An increased incidence of adverse skin reactions was provoked by N95 masks (95.1\%), followed by latex gloves (88.5\%), and then protective clothing (60.7\%). Nasal bridge scarring was the most prevalent skin manifestation due to wearing N95 (68.9\%), whereas latex gloves and protective clothing resulted in dry skin (55.7\% and 36.1\%, respectively). These adverse skin reactions were found to be related to an exposure of at least 10 hours daily for 3.5 months [17].

The study that was conducted on the highest number of medical staff $(4,306)$ and investigated the effects of level-2 and level-3 PPE reported a prevalence of skin injuries of $42.8 \%$, with the main injuries being pressure injuries and skin damage associated with moist skin. Prolonged usage of PPE for more than four hours daily, being male, using level-3 PPE, and sweating were associated with skin injuries [18].

Another study that included 1,106 health professionals did not report specific investigated PPE; however, it showed that the prevalence of pressure injuries due to the use of PPE occurred among 69.4\%, with an average of 2.4 injuries per practitioner tested. The occurrence of such injuries was associated with age $(<35$ years old), wearing PPE for more than six hours daily, no usage for inputs for protection, and hospital unit [19].

One study reported that the prevalence of dermatoses due to PPE was $73.5 \%$ and hand dermatitis was 83\% [20]. These values are far higher when compared to previous studies, which reported that hand dermatitis was prevalent among only $45 \%$ of participants [12]. Pressure injuries and acne were the most prevalent dermatoses associated with PPE [20].

Another study investigating the impact of wearing level-2 and level-3 PPE reported a prevalence of skin reactions of $66.5 \%$, of which $73.7 \%$ were females, $82.7 \%$ were doctors, and $43.6 \%$ of them had only worn level-2 PPE. The prolonged wearing of PPE for >seven hours, gender, age, the frequency of hand hygiene, and the level of PPE worn were associated with the adverse skin reactions among HCWs [21].

\section{Discussion}

The epidemiology of skin diseases related to masks has been rarely reported before, and most reports were case reports [10]. Nowadays, with the emergence of COVID-19 infection and the requirements for wearing PPE for a long time for both the general population and healthcare providers, there are several studies investigating the adverse skin reactions due to PPE. We included 10 studies to assess such dermatological manifestations, their prevalence, and risk factors increasing their incidence combined with the PPE.

The current lack of treatment for COVID-19 made the preventive measures such as wearing masks to be a crucial step to slow and prevent the transmission between the infected and healthy individuals [22]. 
However, the prolonged duration of mask contact could increase the burden of allergic contact dermatitis [23].

In this systematic review, we could identify several dermal conditions associated with wearing PPE as reported in different studies from different regions in the world. The prevalence of the dermatological adverse reaction varied from $42.8 \%$ to $95.1 \%$ [17,18]. The prevalence of such conditions and their types vary between the different studies included, and this returns to the variation in the study populations and their skin susceptibility, the time investigated for the usage of PPE, and the risk factors. However, we could identify that eczema, especially hand eczema, acne, skin rashes, itchy symptoms, and pressure injuries, were the most common dermatological complications of wearing PPE.

A case of a 32-year-old nursing male suffering occupational contact dermatitis on his face on a background of mild acne, which was found to be related to dibromo-dicyanide-butane released from the recently introduced surgical mask was published in 2017 before the outbreak of COVID-19. Additional proof of the correlation between the use of mask and his condition was the significant improvement of the clinical presentation of the patient after avoiding the use of the mask [24].

The included studies investigated the impact of wearing PPE for different durations including, $\geqslant$ four hours, $\geqslant$ seven hours, or a mean of 9.2 hours daily. The adverse skin reactions were significantly more apparent among individuals wearing PPE for $\geqslant$ four hours daily. Also, being a healthcare provider made the individual more prone to suffer adverse skin reactions compared to the general population; this can be related to the long duration the healthcare providers spent in the healthcare setting. Moreover, the position of the healthcare provider was also a determinant factor for the incidence of adverse skin reactions, where seniors were more prone to suffer dermatological complications compared to juniors, and both were more prone to suffer dermatological complications compared to nurses [16].

The prevalence and the type of adverse skin reactions were affected by the PPE type and level; it was found that wearing N95 was associated with a higher incidence of adverse skin reactions [17]. Also, wearing the surgical mask was a risk factor for developing adverse skin reactions compared to wearing a cloth mask [15]. Though level III PPE was associated with discomfort [16] and skin injuries [18], a study reported that level two PPE resulted in a higher frequency of skin reactions (43.6\%) compared to level III PPE (37.6\%) [21]. The type of skin reaction and complication was affected by the type of protective measures used; wearing N95 masks was associated with nasal bridge scarring and facial itching, whereas latex gloves resulted in dry skin, itching, and rashes, and wearing protective clothing resulted in dry skin and itching [17].

The hygiene and its frequency were associated with the incidence of dermal complications. Hand eczema was one of the most common occupational dermatological diseases due to the usage of PPE and increased hand hygiene in the hospital and public settings [12]. Moreover, hygiene-related hand dermatitis was found to occur among $83 \%$ of healthcare providers [20].

All of these adverse skin reactions and complications that occurred due to the use of PPE made authors suggest that they can result in poor adherence and hence increase the risk for infection [13]. Therefore, it was suggested that the design of PPE should be modified to accommodate a range of face shapes and materials to improve the safety of the protective tool and to be gentle on the skin. Also, the guidelines can be improved for the usage of PPE to protect skin health [14].

Another study suggested using virtual occupational health checks to prevent serious skin damage among healthcare providers [25]. Hydrocolloid dressings have been suggested to be used in order to improve comfort and reduce skin damage among those using facial masks [26]. The use of hydrogel patches was found to reduce the skin reaction by almost 10 times compared to the non-users [27]. Regarding pressure injuries, the use of a correctly fitted mask can reduce friction.

\section{Conclusions}

Dermatologic complications are more common due to the usage of PPE or face masks during the COVID-19 pandemic. The most commonly reported skin conditions were eczematous eruptions, acne, erythematous rashes, dry hand skin, and pressure injuries such as nasal bridge scaring. The length of exposure time and the magnitude of protective measures used have been linked to the onset and severity of these cutaneous complications; healthcare providers who wore full PPE for longer durations reported a higher incidence of dermatological complications compared to the general population. Moreover, a higher professional ranking, like seniors, and an older age have been associated with increased risk of side effects from PPE among HCWs, which could be explained by their increased responsibilities and longer exposure time. On the other hand, subjects of the general population suffered mostly from dry hands, rashes around the ears, and acne along mask borders. Increased contact time and infrequent change of face masks were significant risk factors for the development of these skin complications in the general population. These adverse skin reactions to PPE and face masks may lead to poor adherence to their use, thus increases the possibility of unprotected exposure to the virus. Therefore, using the proper type of protective measures, minimizing the duration of exposure, and replacing the used masks frequently are all recommended to avoid adverse skin reactions and 


\section{Additional Information \\ Disclosures}

Conflicts of interest: In compliance with the ICMJE uniform disclosure form, all authors declare the following: Payment/services info: All authors have declared that no financial support was received from any organization for the submitted work. Financial relationships: All authors have declared that they have no financial relationships at present or within the previous three years with any organizations that might have an interest in the submitted work. Other relationships: All authors have declared that there are no other relationships or activities that could appear to have influenced the submitted work.

\section{References}

1. Marraha F, Al Faker I, Gallouj S: A review of the dermatological manifestations of coronavirus disease 2019 (COVID-19). Dermatol Res Pract. 2020, 2020:9360476. 10.1155/2020/9360476

2. Singhal T: A review of coronavirus disease-2019 (COVID-19). Indian J Pediatr. 2020, 87:281-6. 10.1007/s12098-020-03263-6

3. Zhang LP, Wang M, Wang Y, Zhu J, Zhang N: Focus on the 2019 novel coronavirus (SARS-CoV-2). Future Microbiol. 2020, 15:905-18. 10.2217/fmb-2020-0063

4. Abd El-Aziz TM, Stockand JD: Recent progress and challenges in drug development against COVID-19 coronavirus (SARS-CoV-2) - an update on the status. Infect Genet Evol. 2020, 83:104327. 10.1016/j.meegid.2020.104327

5. Feng S, Shen C, Xia N, Song W, Fan M, Cowling BJ: Rational use of face masks in the COVID-19 pandemic . Lancet Respir Med. 2020, 8:434-6. 10.1016/S2213-2600(20)30134-X

6. Zhou NY, Yang L, Dong LY, et al.: Prevention and treatment of skin damage caused by personal protective equipment: experience of the first-line clinicians treating 2019-nCoV infection [IN PRESS]. Int J Dermatol Venereol. 2020, 10.1097/JD9.0000000000000085

7. O'Dowd K, Nair KM, Forouzandeh P, et al.: Face masks and respirators in the fight against the COVID-19 pandemic: a review of current materials, advances and future perspectives. Materials (Basel). 2020, 13:3363. 10.3390/ma13153363

8. Lin P, Zhu S, Huang Y, et al.: Adverse skin reactions among healthcare workers during the coronavirus disease 2019 outbreak: a survey in Wuhan and its surrounding regions. Br J Dermatol. 2020, 183:190-2. 10.1111/bjd.19089

9. Oberg T, Brosseau LM: Surgical mask filter and fit performance. Am J Infect Control. 2008, 36:276-82. 10.1016/j.ajic.2007.07.008

10. Al Badri FM: Surgical mask contact dermatitis and epidemiology of contact dermatitis in healthcare workers . Curr Allergy Clin Immunol. 2017, 30:183-188.

11. Liberati A, Altman DG, Tetzlaff J, et al.: The PRISMA statement for reporting systematic reviews and metaanalyses of studies that evaluate healthcare interventions: explanation and elaboration. BMJ. 2009, 339:b2700. 10.1136/bmj.b2700

12. Uthayakumar AK, Panagou E, Manam S, et al.: PPE-associated dermatoses: effect on work and wellbeing . Future Healthc J. 2021, 8:e67-9. 10.7861/fhj.2020-0210

13. Purushothaman PK, Priyangha E, Vaidhyswaran R: Effects of prolonged use of facemask on healthcare workers in tertiary care hospital during COVID-19 pandemic. Indian J Otolaryngol Head Neck Surg. 2020, 73:59-65. 10.1007/s12070-020-02124-0

14. Abiakam N, Worsley $\mathrm{P}$, Jayabal $\mathrm{H}$, et al.: Personal protective equipment related skin reactions in healthcare professionals during COVID-19. Int Wound J. 2021, 18:312-22. 10.1111/iwj.13534

15. Techasatian L, Lebsing S, Uppala R, et al.: The effects of the face mask on the skin underneath: a prospective survey during the COVID-19 pandemic. J Prim Care Community Health. 2020, 11:2150132720966167. 10.1177/2150132720966167

16. Yuan N, Yang WX, Lu JL, Lv ZH: Investigation of adverse reactions in healthcare personnel working in Level 3 barrier protection PPE to treat COVID-19. Postgrad Med J. 2021, 97:351-4. Accessed: Jun 18: 10.1136/postgradmedj-2020-137854

17. Hu K, Fan J, Li X, Gou X, Li X, Zhou X: The adverse skin reactions of health care workers using personal protective equipment for COVID-19. Medicine (Baltimore). 2020, 99:e20603. 10.1097/MD.0000000000020603

18. Jiang Q, Song S, Zhou J, et al.: The prevalence, characteristics, and prevention status of skin injury caused by personal protective equipment among medical staff in fighting COVID-19: a multicenter, cross-sectional study. Advances in wound care. 20201, 9:357-64. 10.1089/wound.2020.1212

19. Coelho MM, Cavalcante VM, Moraes JT, Menezes LC, Figueirêdo SV, Branco MF, Alexandre SG: Pressure injury related to the use of personal protective equipment in COVID-19 pandemic. Rev Bras Enferm. 2020, 73:e20200670. 10.1590/0034-7167-2020-0670

20. Shanshal M, Ahmed HS, Asfoor H, Salih RI, Ali SA, Aldabouni YK: Impact of COVID-19 on medical practice: a nationwide survey of dermatologists and health care providers in Iraq [IN PRESS]. Clin Dermatol. 2020, 10.1016/j.clindermatol.2020.11.010

21. Christopher PM, Roren RS, Tania C, Jayadi NN, Cucunawangsih C: Adverse skin reactions to personal protective equipment among health-care workers during COVID-19 pandemic: a multicenter cross-sectional study in Indonesia. Int J Dermatol Venereol. 20201, 3:211-8. 10.1097/JD9.0000000000000132

22. Tirupathi R, Bharathidasan K, Palabindala V, Salim SA, Al-Tawfiq JA: Comprehensive review of mask utility and challenges during the COVID-19 pandemic. Infez Med. 2020, 28:57-63.

23. Xie Z, Yang YX, Zhang H: Mask-induced contact dermatitis in handling COVID-19 outbreak . Contact Dermatitis. 2020, 83:166-7. 10.1111/cod.13599 


\section{Cureus}

24. Yin ZQ: Covid-19: countermeasure for N95 mask-induced pressure sore . J Eur Acad Dermatol Venereol. 2020, 34:e294-5. 10.1111/jdv.16490

25. Payne A: Covid-19: skin damage with prolonged wear of FFP3 masks . BMJ. 2020, 369:m1743.

10.1136/bmj.m1743

26. Dong L, Yang L, Li Y, et al.: Efficacy of hydrogel patches in preventing facial skin damage caused by mask compression in fighting against coronavirus disease 2019: a short-term, self-controlled study. J Eur Acad Dermatol Venereol. 2020, 34:e441-3. 10.1111/jdv.16638

27. Bhatia R, Sindhuja T, Bhatia S, Dev T, Gupta A, Bajpai M, Gupta S: Iatrogenic dermatitis in times of COVID19: a pandemic within a pandemic. J Eur Acad Dermatol Venereol. 2020, 34:e563-6. 10.1111/jdv.16710 